\title{
DIRECTIONS OF RE-EQUIPMENT OF PORTS OF UKRAINE DUE TO MODERN CRANES
}

\section{Tkachuk Kateryna ${ }^{1}$}

DOI: https://doi.org/10.30525/978-9934-571-89-3_122

In the structure of cargo turnover of sea and river ports of Ukraine there is an need for efficient, reliable, universal lifting machines, namely, portal cranes, which are among the most common means of mechanization, performing up to $70 \%$ of the volume of loading and unloading operations.

In the ports of Ukraine, the centralized planned supply of cranes ceased in the early 90 s of the last century. Over the past 20 years, the structure of the park of gantry cranes has changed slightly [1, p. 205].

Most of the cranes in the ports are cranes such as "Falcon", "Albatross", "Condor", "Mark" with articulated boom system and boom balancing system.

In the same 90-ies, foreign crane companies (Liebherr, Gottwald) began to produce mobile port cranes with a straight boom without a boom balancing system.

These cranes began to be used in foreign ports, as well as in several ports of Ukraine and Russia.

Currently, there is an active discussion on the prospects for technical re-equipment of ports by cranes [2, p. 18, 3-5], but no convincing decisions and an agreed strategy have yet been worked out.

The solution of this problem is influenced by many factors: the scale of the port, its cargo turnover, the type of cargo, the state of the berths and the crane fleet, the type and deadweight of the vessels, the technology of transshipment processes, economic opportunities.

As a result, it can be noted that the economy and these factors force each port to make its own individual choice [6, p. 161].

Based on the discussion and analysis of the development of the ports, there are four main areas in which the load-lifting fleet is being re-equipped.

1) Modernization of existing gantry cranes. It includes the replacement of relaycontactor control systems for electric drive mechanisms for frequency, the replacement of mechanisms, safety devices and control. The high cost of such systems pays off with high efficiency by reducing the power consumption by up to $30 \%$ and increasing the service life of the crane by $10-12$ years [7, p. 21].

\footnotetext{
${ }^{1}$ Pryazovskyi State Technical University, Ukraine
} 
2) Updating the fleet of gantry cranes with new traditional cranes with articulated boom system and balancing system.

Ukrainian ports have a peculiarity - most of them are connected with the railway. One of the main tasks of the port cranes was and remains the processing of wagons and gondola cars with bulk cargoes. In this regard, in numerous works [5-6] it is recommended to use articulated boom systems for gantry cranes, where the suspension point moves along a trajectory close to horizontal when the boom reach changes, while the suspension length is minimal, which reduces the free oscillations of the load and improves the performance of the crane.

In addition, due to the movable counterweight at maximum departure, cranes with articulated boom systems have a large carrying capacity. The change of departure in this type of cranes occurs without the inclusion of a lifting mechanism, which reduces the energy consumption of the crane and does not increase the swinging of the load. Articulated boom system does not need complex designs equalizing blocks, tackles or drums, prematurely wearing ropes and requiring adjustment and maintenance.

With all the advantages of the articulated boom system, the replacement and renewal of the fleet of vehicles with this design can become rational in cost and provide the most favorable conditions for the provision of replaceable spare parts. Moreover, Ukraine has the experience and the possibility of producing such cranes, even on a competitive basis, by a number of plants: NKMZ (Kramatorsk), Azovmash (Mariupol), Konecranes Ukraine (Zaporizhia). All these plants already have developed projects and experience in manufacturing new cranes.

These projects include the installation of progressive control systems on the cranes, ensuring a reduction in energy consumption - up to $30 \%$.

The projects of these cranes were developed jointly with foreign firms "Kranbau Eberswalde", "Noell", "Konecranes".

3) Equipping of ports with mobile cranes with direct boom and increased lifting capacity up to $75-100$ tons $[2$, p. 18,3$]$.

The use of such cranes is effective when processing large-tonnage vessels on deepwater berths of ports. There are only 6-7 such ports in Ukraine, but at least 12-14 sea, as well as river and fish ports need in cranes of medium and low payload.

The experience of using mobile cranes has sea ports in Odessa and Yuzhny, where there are 5 Gottwald cranes, a port in Novorossiysk - 5 Gottwald cranes and 2 Liebherr cranes.

In modern construction of portal cranes of foreign manufacturers, control and damping of oscillations is carried out through the use of automated anti-sway systems, for example, the Liebherr Cycoptronic system, which allows controlling the process of cargo movement [8; 9]. However, the practice of operating cranes equipped with an automated anti-sway system has shown that this system is characterized by a long delay in subsequent movement, a slow response of the crane to acceleration. In addition, the recommended electronic systems require automatic control of all operations related to the operation of the crane, which is not always possible for domestic manufacturers due to the high cost of such equipment. 
One of the advantages of straight arrows is the absence of boom torsion, but the author [7] notes the presence of deformations of the upper end of the arrow caused by increased stresses from significant bending moments. The disadvantages of the construction of straight arrows include a large rope capacity, which is the cause of numerous accidents.

4) Re-equipment of existing gantry cranes with installation on their portal of a new turntable with mechanisms and direct boom system, similar to the turning part of a mobile crane.

Mobile loading cranes operate on their own diesel generator, which significantly increases the cost and maintenance of these machines. In addition, the movement mechanism has a hydraulic drive, and management of all operations is carried out using a digital controller and a computer.

This version of the refitted crane works in the port of Tuapse and so far does not find distribution.

The above information allows us to conclude that in the foreseeable future, the main type of lifting machine in the ports of Ukraine will remain the traditional type of portal crane with articulated boom system and balancing system.

Production of new cranes, of course, should be carried out on improved projects, taking into account the use of progressive solutions, and on operating cranes, modernization has been carried out with improved operational and technical characteristics.

And in this and in another case, the quality of the crane will largely depend on the quality of the boom system and the balancing system.

\section{References:}

1. Panova Z.N. (2012). Analiz travmatizma i avariynosti pri ekspluatatsii gruzopod"emnykh kranov [Analysis of injuries and accidents during the operation of load-lifting cranes]. Journal "The Bulletin of Kras GAU”, no. 7, pp. 175-180.

2. Andrienko A.A. (2011). Optymizacija parametriv ta strateghija onovlennja strilovykh perevantazhuvaljnykh kraniv $\mathrm{v}$ morsjkykh portakh Ukrajiny [Optimization of parameters and strategy for updating cranes overload cranes in the seaports of Ukraine] (PhD Thesis), Odessa: Odessa national maritime university.

3. Furtatov Y. (2011). Perspektivnye napravleniya v portovom kranostroenii [Promising areas in the port crane industry]. Porty Ukrainy (electronic journal), vol. 6, no. 108, pp. 8-10. Retrieved from: http://portsukraine.com/node/2176 (accessed 10 March 2013).

4. Pustovoy V.N. (2010) Kakoy kran nuzhen morskomu portu [What crane does the seaport need]. Porty Ukrainy (electronic journal), vol. 7, no. 99, pp. 12-14. Retrieved from: http://portsukraine.com/node/1887 (accessed 14 March 2013).

5. Pelashenko S. (2012). Krany nuzhny raznye [Cranes need different]. Porty Ukrainy (electronic journal), vol. 4, no. 116, pp. 22-23. Retrieved from: http://portsukraine.com/node/2796 (accessed 14 March 2013).

6. Prodius O., Vlasenko M. (2015). Problemy morskikh konteynernykh perevozok v Ukraine [Problems of container shipping in Ukraine]. Journal "The Bulletin of Odessa National Polytechnic University", no. 33, pp. 147-161.

7. Tkachuk K.V. (2017). Obgruntuvannja racionaljnykh konstruktyvnykh parametriv sharnirnozchlenovanykh strilovykh system portaljnykh kraniv [Justification of the rationale design 
parameters of the hinge-articulated jib portal crane system] (PhD Thesis), Kharkov: Ukrainian engineering pedagogics academy.

8. Fetah Kolonic, Alen Poljugan, Ivan Petrovic. Tensor Product Model Transformation-based Controller Design for Gantry Crane Control System - An Application Approach // Acta Polytechnica Hungarica. Vol. 3, No. 4, 2006, 95-112 pp.

9. Keqin LI Inverse Design of a New Double-link Luffing Mechanism and Realization on MATLAB / Keqin LI, Cuxiang JIANG // Proceedings of the 3rd ICMEM International Conference on Mechanical Engineering and Mechanics October 21-23, 2009, Beijing, P. R. China, pp. 301-304. 